Volume 11 Number 1 May 2021 Page. 59-66

Journal Homepage : http://teknois.stikombinaniaga.ac.id/index.php/JBS

DOI Link : http://doi.org/10.36350/jbs.v11i1

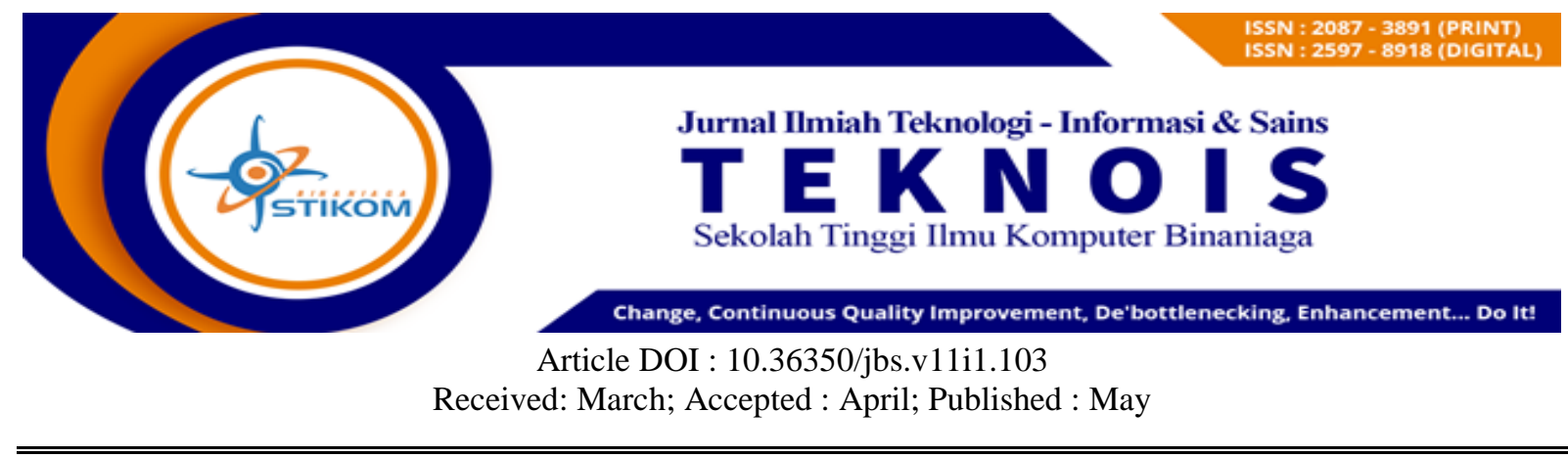

\title{
Penerapan Representational State Transfer (REST) Pada Push Notification Whatsapp Untuk Layanan Informasi Akademik
}

\author{
Anggra Triawan ${ }^{1 *}$, Wisnu Alipudin ${ }^{2}$ \\ ${ }^{1}$ Sistem Informasi/STIKOM Binaniga \\ Email: anggra@stikombinaniaga.ac.id \\ ${ }^{2}$ Teknik Informatika/STIKOM Binaniga \\ Email: wisnualipudin@gmail.com
}

\begin{abstract}
Higher education is an educational institution within the national education system in all countries. Its position is not much different from primary or secondary education, which functions to develop the potential of students to grow and develop as normal members of society, but universities have a mission that goes beyond just providing graduates who are smart, reliable in their knowledge organization and able to apply in the world of work. . Higher education must be able to deliver students to understand themselves, determine their role in society and as human beings who are much better than before. Push notifications, a service that is widely used for notifications via short messages on smartphones. With the Push Notification service, users can be helped in terms of brief notifications. In its implementation, Push Notification can be used in various daily needs, for example to monitor attendance, update the latest news, and so on, by combining whatsapp and academic push notifications will result in a search for values very easily when using the WhatsApp application.
\end{abstract}

Keywords:Rest API; Push Notification; WhatsApp.

\begin{abstract}
ABSTRAK
Perguruan tinggi merupakan lembaga pendidikan yang tertinggi dalam sistem pendidikan nasional di semua negara. Posisinya tidak jauh berbeda dengan pendidikan dasar atau menengah yang berfungsi untuk mengembangkan potensi peserta didik agar tumbuh dan berkembang sebagai anggota masyarakat yang normal tetapi perguruan tinggi memiliki misi yang lebih jauh dari sekedar menghasilkan lulusan yang pandai, handal dalam mengelola ilmunya dan mampu menerapkan dalam dunia kerja. Perguruan tinggi harus bisa mengantarkan peserta didiknya memahami dirinya sendiri, menentukan peran dirinya dalam masyarakat dan menjadikannya sebagai manusia yang jauh lebih baik dari yang sebelumnya. Push Notification sebuah layanan yang banyak digunakan untuk keperluan pemberitahuan melalui pesan pendek yang ada di smartphone. Dengan adanya layanan Push Notification tersebut, pengguna dapat terbantu dalam hal yang bersipat pemberitahuan secara singkat. Pada implementasinya Push Notification dapat dimanfaatkan dalam berbagai keperluan sehari-hari misalnya untuk monitoring absensi, update berita terbaru, dan sebagainya, dengan memadukan push notifikasi whatsapp dan rest akademik akan menghasilkan pencarian nilai dengan sangat mudah jika menggunakan aplikasi whatsapp.
\end{abstract}

Keywords: Rest API; Push Notification; WhatsApp. 


\section{A. PENDAHULUAN}

\section{Latar Belakang}

Pengolahan data informasi akademik merupakan suatu hal mutlak yang sangat diperlukan bagi instansi-instansi pendidikan seperti universitas, terlebih di jaman yang serba modern seperti sekarang ini, dimana penyajian informasi dituntut tidak hanya harus akurat tapi juga bisa diperoleh dengan mudah dan cepat. Untuk menyajikan informasi yang cepat dan akurat ini, maka dalam proses pengolahan data harus dilakukan secara terkomputerisasi dalam sebuah sistem yang biasa disebut sistem informasi, dengan dilakukannya proses pengolahan data secara terkomputerisai. Peran sistem informasi terhadap kemajuan organisasi maupun instansiinstansi pendidikan seperti Universitas sudah tidak diragukan lagi. Dengan dukungan sistem informasi yang baik maka sebuah Universitas akan memiliki berbagai keunggulan yang kompetitif sehingga mampu bersaing dengan Universitas lain.

Kemunculan WhatsApp Messenger yang memiliki interface sendiri membuat penggunanya makin dimanjakan, kemampuan mengirim gambar, video, suara, dan kontak menjadi salah satu kemudahan dalam berkomunikasi. Ada fitur terbaru yang diluncurkan adalah Broadcast Message untuk berkomunikasi, berbagi informasi dengan banyak orang

WhatsApp Messenger merupakan aplikasi pesan seluler lintas platform yang memungkinkan pengguna bertukar pesan tanpa harus membayar biaya SMS, karena WhatsApp Messenger menggunakan paket data internet yang sama untuk Email, Browsing Web, dan lain-lain. Aplikasi WhatsApp Messenger menggunakan koneksi GPRS, EDGE, 3G atau WiFi untuk komunikasi data, dengan menggunakan WhatsApp Messenger pengguna dapat melakukan obrolan Online, berbagi file, musik, lokasi, bertukar foto, video dan lain-lain

Tercatat lebih dari separuh penduduk Indonesia bermain media sosial. Begitu laporan terbaru per Januari 2019 da, ri We Are social, perusahaan asal Inggris bekerja sama dengan Hootsuite, Dari total populasi penduduk yang mencapai 268,2 juta tercatat ada 355,5 juta pelanggan seluler. Masyarakat Indonesia yang sudah menggunakan internet menyentuh angka 150 juta. Dari angka tersebut, semuanya aktif di media sosial. Bila dilihat dari pertumbuhannya sejak Januari tahun lalu, maka pelanggan seluler menurun 19\% (83 juta pelanggan), pengguna internet tumbuh $13 \%$ (17 juta pengguna internet), dan yang aktif berselancar di media sosial pun tumbuh pesat sampai $15 \%$ atau tumbuh 20 juta pengguna.

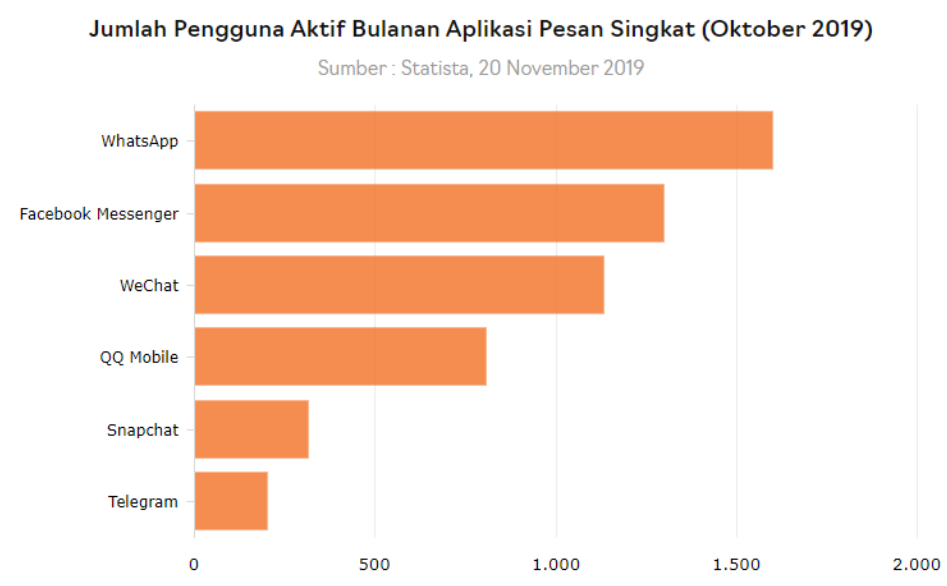

Gambar 1. Sosial media paling popular di Indonesia (2019)

\section{Permasalahan}

Dari pemaparan uraian latar belakang diatas, jika dilihat dari konsep dalam metode REST maka dapat diidentifikasi masalah dalam penelitian ini adalah :

a. Belum diketahui infrastruktur yang diterapkan Push Notif pada informasi akademik .

b. Belum teridentifikasikan fungsi dari GET dan POST pada informasi akademik.

c. Belum adanya informasi yang disampaikan dimedia sosial secara Real Time. 
Volume 11 Number 1 May 2021 Page. 59-66

Journal Homepage : http://teknois.stikombinaniaga.ac.id/index.php/JBS

DOI Link : http://doi.org/10.36350/jbs.v11i1

\section{Tujuan}

Adapun tujuan dari penelitian ini adalah :

a. Untuk mengetahui dan diterapkannya konsep infrastruktur REST pada Push Notif di sistem informasi akademik.

b. Untuk mengetahui konsep yang digunakan dalam metode GET dan POST.

c. Untuk mendapatkan notifikasi informasi akademik di media sosial.

\section{Tinjauan Pustaka}

\section{a. Push Notification}

Push Notification adalah sebuah layanan yang banyak digunakan untuk keperluan pemberitahuan melalui pesan pendek yang ada di smartphone. Dengan adanya layanan Push Notification tersebut, pengguna dapat terbantu dalam hal yang bersipat pemberitahuan secara singkat. Pada implementasinya Push Notification dapat dimanfaatkan dalam berbagai keperluan sehari-hari misalnya untuk monitoring absensi, update berita terbaru, dan sebagainya. Aplikasi yang akan dirancang adalah sebuah aplikasi yang dapat mengirim Push Notification yang nantinya akan dapat dikembangkan di berbagai bidang sesuai dengan kebutuhan pengguna. Kurangnya pengetahuan dalam memberikan informasi secara real time, berakibat informasi yang tersampaikan tidak upto-date, sehingga dalam berbagai situasi dan kondisi informasi yang diberikan telah usang. Push Notification salah satu layanan yang dapat menjawab masalah tersebut sehingga tidak ada lagi informasi yang terbaru tidak tersampaikan, dengan penggunaan layanan ini setiap terjadi update informasi maka akan langsung terkirim sebagai pesan notification, sehingga informasi yang terbaru tidak akan terlewatkan. Layanan Push Notification umumnya banyak diterapkan pada aplikasi mobile seperti Android dan IOS. Untuk penggunaan Sistem Operasi mobile terbesar berdasarkan statcounter untuk tahun 2012 sampai 2020 di Indonesia dikuasi oleh Sistem Operasi Android. Berbasarkan data tersebut pengembangan aplikasi Push Notification ini diterapkan pada Sistem Operasi Andoid sebagai pangsa pasar terbesar saat ini.

Untuk dapat mengimplementasikan layananan Push Notification diperlukan cloud server, salah satu cloud server yang bias digunakan adalah Fire Base. Fire Base adalah layanan pada Google Cloud Messaging (GCM) yang membantu pengembang mengirim data dari server untuk aplikasi mereka Android pada perangkat Android. Ini bisa menjadi pesan ringan memberitahu aplikasi Android bahwa ada data baru yang akan diambil dari server (misalnya, film diunggah oleh seorang teman), atau bisa juga pesan yang berisi sampai dengan $4 \mathrm{~KB}$ data payload (sehingga aplikasi seperti instant messaging dapat mengkonsumsi pesan langsung). Layanan GCM menangani semua aspek antrian pesan dan pengiriman ke aplikasi target Android berjalan pada perangkat target. GCM memungkinkan aplikasi android untuk mngirimkan pesan kepada server untuk membroadcast sebuah notifikasi kepada seluruh client yang ada. Hanya membutuhkan sebuah account Gmail maka akan langsung dapat menggunakan fasilitas GCM ini. (Santoso, 2012).

\section{b. Whatsapp}

WhatsApp dapat digunakan untuk pengguna iPhone, BlackBerry, Android, serta Symbian (Nokia). Aplikasi WhatsApp hanya dapat bekerja untuk sesame pengguna yang memiliki aplikasi WhatsApp. Aplikasi WhatsApp ini dapat diunduh secara gratis di websitenya. Aplikasi ini menggunakan nomor telepon ponsel yang kita gunakan untuk berinteraksi dengan sesama pengguna WhatsApp. Aplikasi ini memungkinkan pengguna BlackBerry, Android, iPhone, dan Symbian, serta Windows Phone untuk dapat saling berkomunikasi satu sama lain. Aplikasi ini menggunakan fitur push sehingga Anda dapat selalu memberitahukan pesan yang sedang diterima. Beberapa hal yang perlu diperhatikan dalam penggunaan WhatsApp. 
Volume 11 Number 1 May 2021 Page. 59-66

Journal Homepage : http://teknois.stikombinaniaga.ac.id/index.php/JBS

DOI Link : http://doi.org/10.36350/jbs.v11i1

WhatsApp ini mengandalkan koneksi internet melalui jaringan GPRS/EDGE/3G atau wifi untuk menjalankannya. Aplikasi WhatsApp ini tidak keluar (log out) saat tidak tersambung dengan koneksi internet. Anda dapat melihat kontak maupun perbincangan dengan teman Anda walaupun tidak tersambung dengan koneksi internet. Seperti pada BlackBerry Messenger, apabila tidak tersambung dengan koneksi internet, Anda tetap dapat membuka aplikasi tersebut, tetapi saat Anda coba untuk mengirim pesan, terdapat tanda jam yang menandakan pesan Anda ditunda pengirimannya sampai terdapat koneksi internet.

\section{B. METODE}

Penelitian ini dilaksanakan untuk menerapkan konsep insfrastuktur REST API berdasarkan GET dan POST dan menggunakan metode uji yaitu menggunakan kuesioner sebagai teknik untuk mendapatkan tanggapan dari responden. Responden yang digunakan adalah mahasiswa.

\section{Desain Penelitian}

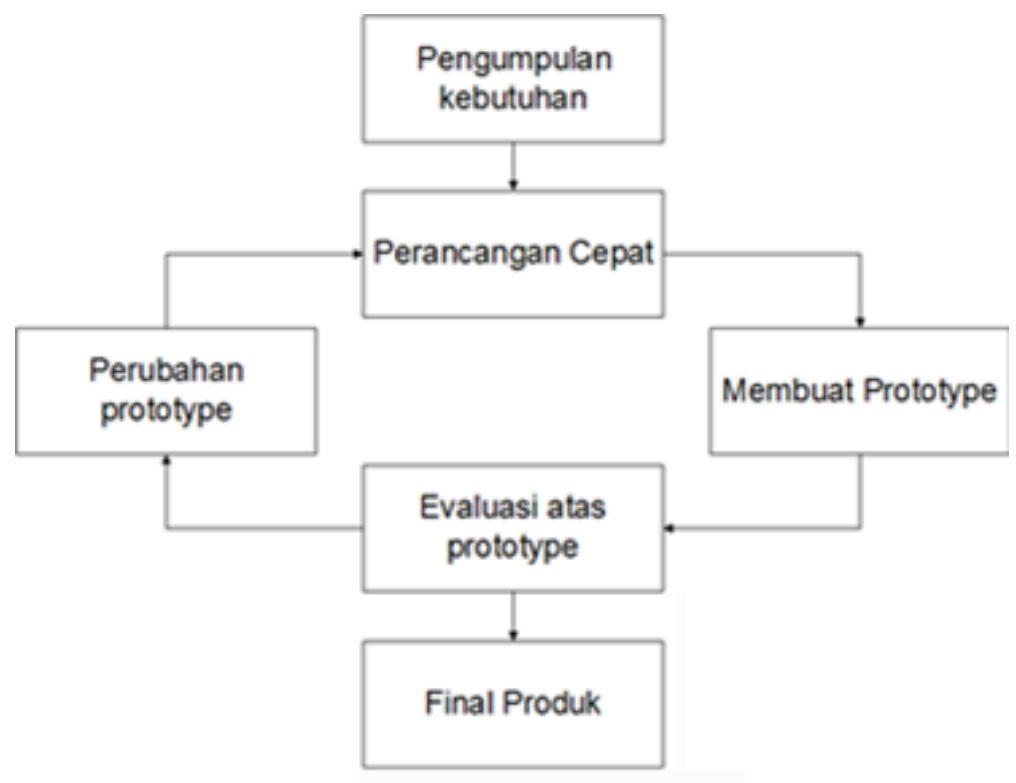

Gambar 2. Prosedur Penelitian

Proses dari prosedur penelitian yang dilakukan sebanyak 7 kegiatan yaitu tahap pertama adalah pengumpulan kebutuhan analisa dimana pelanggan dan pengembang bersama-sama mendefinisikan format seluruh perangkat lunak, menganalisis semua kebutuhan dan garis besar sistem yang akan dibuat. Tahap kedua adalah perancangan cepat dimana perencanaan dilakukan cepat dan rancangan mewakili semua aspek software yang diketahui, dan rancangan ini menjadi dasar pembuatan prototype. Tahap ketiga adalah membuat prototype dimana Membangun design prototyping dengan membuat perancangan sementara yang berfokus pada penyajian kepada pelanggan (misalnya dengan membuat input dan format output). Tahap keempat adalah evaluasi dan prototype dimana evaluasi ini dilakukan oleh pelanggan, apakah prototyping yang sudah dibangun sudah sesuai dengan keinginan pelanggan atau belum. jika sudah sesuai, maka langkah selanjutnya akan diambil. Tahap kelima adalah perubahan prototype dimana prototyping direvisi apabila prototyping belum sesuai maka akan mengulang langkah-langkah sebelumnya. Tahap keenam adalah pengembangan dimana dalam tahap ini prototyping yang sudah di sepakati diterjemahkan ke dalam bahasa pemrograman yang sesuai. Tahap ketujuh adalah Tes Produk dimana setelah sistem sudah menjadi suatu perangkat lunak yang siap pakai, kemudian dilakukan proses pengujian. Pengujian ini dilakukan kepada pengguna. 


\section{Sumber Data}

Dalam pelaksanaan kuesioner, ditentukan terlebih dahulu jumlah responden. Menentukan jumlah responden digunakan rumus slovin. Dalam penelitian ini rumus slovin digunakan untuk menentukan jumlah responden kuesioner uji produk. Besar sampel dalam penelitian ini ditentukan dengan rumus slovin (Sugiyono, 2010) sebagai berikut:

$$
\begin{array}{cl}
n=\frac{N}{1+N e^{2}} & \\
\text { Keterangan: } & \\
\mathrm{n} & =\text { jumlah elemen / anggota sampel } \\
\mathrm{N} & =\text { jumlah elemen / anggota populasi } \\
\mathrm{e} & =\text { error level (tingkat kesalahan) }
\end{array}
$$

\section{Instrumen Penelitıan}

Instrumen yang disusun meliputi satu jenis sesuai dengan peran dan posisi responden dalam pengembangan ini.Bentuk Instrumen tersebut memiliki format pertanyaan terbuka dan tertutup.Pertanyaan terbuka meliputi saran atau masukan dari pengguna maupun ahli. Adapun format pertanyaan tertutup adalah sebagai berikut:

Instrumen yang digunakan untuk ahli sistem adalah berupa kuesioner tertutup. (Sugiyono, 2019, p.406) menyatakan bahwa "Instrumen penelitian adalah alat ukur seperti tes, kuesioner, pedoman wawancara dan pedoman observasi yang digunakan peneliti untuk mengumpulkan data dalam suatu penelitian". Dalam penelitian ini ahli sistem adalah dosen yang paham mengenai sistem. Instrumen yang dipakai adalah pengujian black box. Pengujian black box yaitu menguji perangkat lunak dari segi spesifikasi fungsional tanpa menguji desain dan kode program (Rosa A.S dan M. Shalahudin, 2011). Kategori - kategori kesalahan yang diuji oleh pengujian black box adalah fungsi - fungsi yang salah salah atau hilang, kesalahan interface, kesalahan dalam struktur data atau akses database eksternal, kesalahan performa, kesalahan inisialisasi dan terminasi (Lila, 2018). Black Box Testing berfokus pada spesifikasi fungsional dari perangkat lunak. Tester dapat mendefinisikan kumpulan kondisi input dan melakukan pengetesan pada spesifikasi fungsional program. Black Box Testing bukanlah solusi alternatif dari White Box Testing tapi lebih merupakan pelengkap untuk menguji hal-hal yang tidak dicakup oleh White Box Testing (Mustaqbal et al., 2015).

\section{Teknik Analisa Data}

Dalam penelitian ini, metode analisis data dengan menggunakan presentase kelayakan. Adapun rumus yang digunakan adalah sebagai berikut:

Persentase kelayakan $(\%)=($ Skor yang diobservasi $) /($ Skor yang diharapkan $) \times 100 \%$

Hasil presentase digunakan untuk memberikan jawaban atas kelayakan dari aspek - aspek yang diteliti. Menurut Arikunto (2009, p.44), pembagian kategori kelayakan ada lima. Skala ini memperhatikan rentang dari bilangan presentase. Nilai maksimal yang diharapkan adalah $100 \%$ dan minimum 0\%. Pembagian rentang kategori kelayakan menurut Arikunto (2009, p.44), dapat dilihat pada Tabel 1.

Tabel 1 Kategori Kelayakan Menurut Arikunto

\begin{tabular}{|c|c|}
\hline Presentase Pencapaian & Interpretasi \\
\hline$<21 \%$ & Sangat Tidak Layak \\
\hline $21 \%-40 \%$ & Tidak Layak \\
\hline $41 \%-60 \%$ & Cukup Layak \\
\hline $61 \%-80 \%$ & Layak \\
\hline $81 \%-100 \%$ & Sangat Layak \\
\hline \multicolumn{2}{|c|}{ Sumber : (Arikunto, 2006) }
\end{tabular}




\section{HASIL DAN PEMBAHASAN}

\section{Hasil}

Total score dari hasil pengisian kuesioner secara Overall dari 5 responden adalah 561 Skor diharapkan adalah nilai skala range tertinggi dikali jumlah pertanyaan dikali jumlah responden. Maka skor yang diharapkan $=665$

Dengan menggunakan rumus persentase kelayakan maka :

Pesentase kelayakan $(\%) \quad=109+111+117+112+112 \times 100 \%$

$$
665
$$

$$
\begin{aligned}
& \text { Persentase kelayakan }(\%) \quad=84,37 \% \\
& \text { Persentase kelayakan }(\%) \quad=84,37 \% \\
& \text { Persentase kelayakan }(\%) \quad=84,37 \%
\end{aligned}
$$

Berdasarkan persentase kelayakan maka dapat disimpulkan bahwa sistem aplikasi ini baik dari pengguna petugas perpustakaan dinilai Sangat Layak.

\section{Pembahasan}

Push notifikasi pada penelitian ini diterapkan pada fitur mendapatkan informasi akademik di unbin. nntuk penerapan push notifikasi pada pendapatan informasi akademik bisa dilihat pada

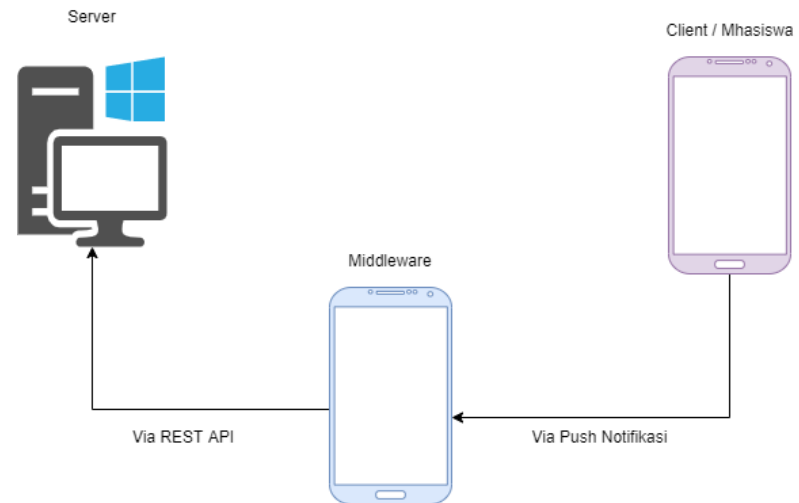

Gambar 3. dengan menggunakan flow push notifikasi dengan rest api

REST adalah metode komunikasi antar dua sistem melalui Hypertext Transfer Protocol (HTTP), melibatkan proses pembacaan laman web tertentu yang memuat sebuah file Extensible Markup Language(XML) atau Javascript Object Notation (JSON). API adalah antarmuka yang digunakan untuk mengakses aplikasi atau layanan sebuah program. API memanggil fungsi REST lewat HTTP untuk mendapatkan respon berupa XML atau JSON. REST API digunakan sebagai penghubung antara bagian data dengan client sehingga pada bagian client dapat mengakses server dan memperoleh data. REST API yang sudah dibuat untuk pecarian ini dikases melalui laman website/url http://172.104.182,146:9350/npm=15160038\&message $=15160038$ nilai. URL tersebut digunakan untuk melakukan request yang diberikan pada layanan informasi akadmik di UNBIN. Request yang dilakukan dengan menggunakan metode GET atau POST. Metode GET atau POST untuk mendapatkan data yang dibutuhkan client.

Pada gambar 5 coding rest api ketika android middleware mengirimkan request ke server maka api akan melakukan query apa yang di request oleh middleware dan kemudian akan diteruskan kembali berupa respon dengan tipe data json yang akan di teruskan kembali menggunakan middleware kepada mahasiswa. 
Volume 11 Number 1 May 2021 Page. 59-66

Journal Homepage : http://teknois.stikombinaniaga.ac.id/index.php/JBS

DOI Link : http://doi.org/10.36350/jbs.v11i1

Tabel 2. Penerapan metode POST

\begin{tabular}{|l|l|l|}
\hline URL & Metode & Pesan \\
\hline$\underline{\text { http://172.104.182.146:9350/query }}$ & POST & Npm dhs \\
\hline http://172.104.182.146:9350/query & POST & Npm pembayaran 2017/2018 \\
\hline$\underline{\text { http://172.104.182.146:9350/query }}$ & POST & Npm perjanjian 2017/2018 \\
\hline
\end{tabular}

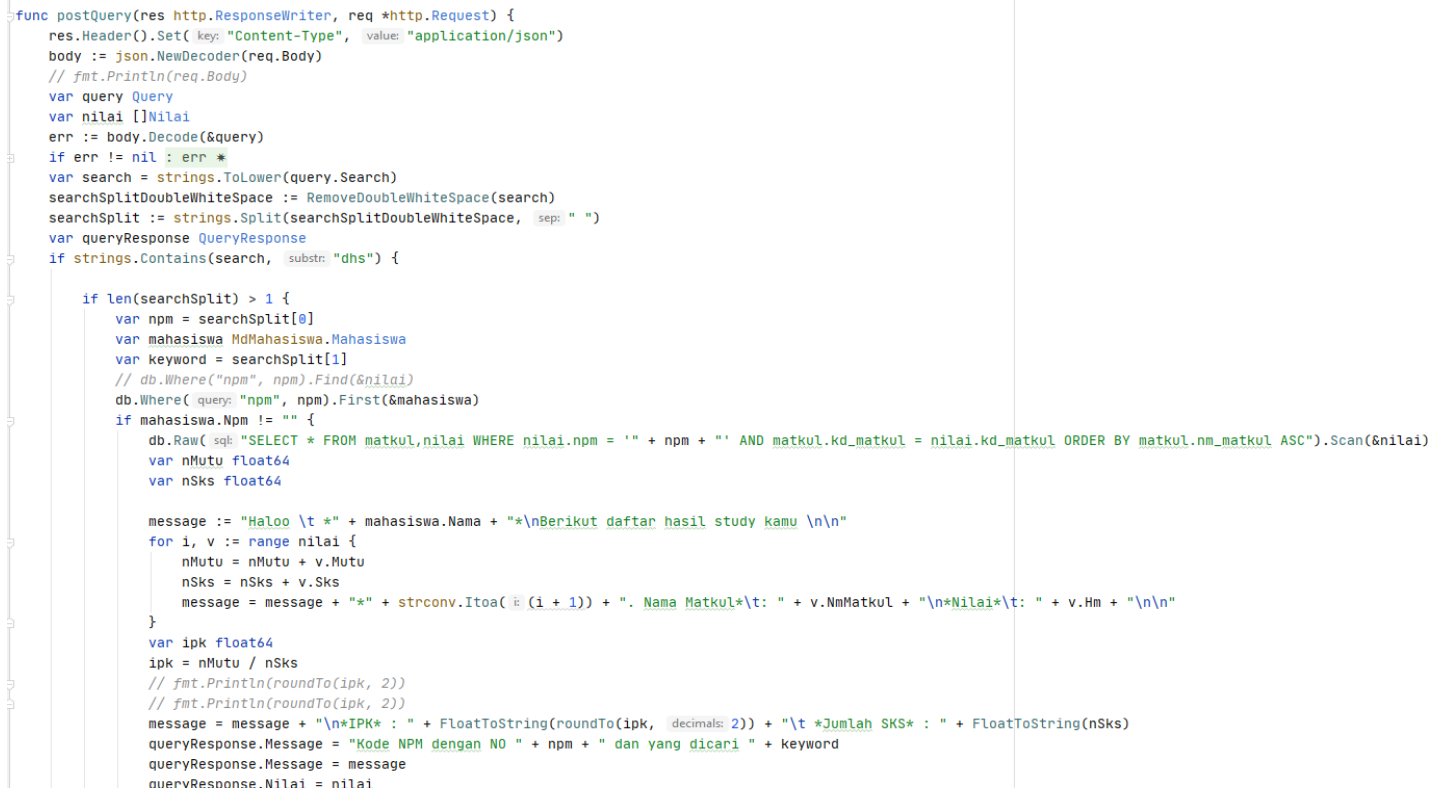

Gambar 4. Code untuk metode GET dan POST

\section{KESIMPULAN}

Berdasarkan penelitian yang telah dilakukan melalui metode REST dengan 2 metode yaitu POST dan GET; dapat diketahui sebagai berikut:

1. Push notifikasi dan dipadukan dengan RESTAPI dapat digunakan mencari informasi akademik, sehingga dapat memudahkan mahasiswa dalam hal mendapatkan informasi seputar informasi akademik.

2. Sistem yang dikembangkan dapat membantu mahasiswa dalam mendapatkan informasi, sistem yang dikembangkan telah melakukan uji kelayakan yang telah dilakukan dan mendapatkan hasil interprestasi "Sangat Layak" pada pengujian untuk pengguna dengan persentase pencapaian $84,37 \%$.

3. Kecepatan akses mempermudah mahasiswa dalam mendapatkan informasi akademik secara cepat, berikut dibawah ini adalah hasil dai pengukurannya :

Tabel 3. Hasil pengukuran kecepatan akses

\begin{tabular}{|l|l|l|l|l|}
\hline NO & $\begin{array}{l}\text { Nama } \\
\text { Mahasiswa }\end{array}$ & Hasil yang di dapat & $\begin{array}{l}\text { Waktu } \\
\text { Sebelum }\end{array}$ & $\begin{array}{l}\text { Waktu } \\
\text { Sesudah }\end{array}$ \\
\hline 1 & $\begin{array}{l}\text { Angga } \\
\text { Sidiyantoro }\end{array}$ & dhs & 60 Detik & $136 \mathrm{~ms}$ \\
\hline 2 & $\begin{array}{l}\text { Rangga } \\
\text { Tirtayana }\end{array}$ & dhs & 40 Detik & $200 \mathrm{~ms}$ \\
\hline 3 & Hairul & dhs & 30 Detik & $150 \mathrm{~ms}$ \\
\hline 4 & Erisya Lastrini & dhs & 1 menit & $120 \mathrm{~ms}$ \\
\hline 5 & Yaumil Ulfa & dhs & 1,5 menit & $130 \mathrm{~ms}$ \\
\hline
\end{tabular}




\section{E. DAFTAR PUSTAKA}

[1] Dewi, F. K. S., Indriasari, T. D., \& Prayogo, Y., 2016. Rancang Bangun Aplikasi Pengingat Kegiatan Akademik Berbasis Mobile. Jurnal Buana Informatika, 7(4), 303-312. https://doi.org/10.24002/jbi.v7i4.771

[2] Kurniawan, E., 2014. Implementasi Rest Web Service Untuk Sales Order Dan Sales Tracking Berbasis Mobile. Jurnal EKSIS, 07, 1-12.

[3] Belakang, L., Sejak, M., Acton, B., Koum, J., Messaging, M., Messaging, L. M., Agustus, H., Messenger, W., Messenger, W., Messenger, W., Messenger, W., Messaging, V., \& Messenger, W., 2013. BAB I PENDAHULUAN. 1-13.

[4] Fallis, A. ., 2013. Bab Ii Landasan Teori. Journal of Chemical Information and Modeling, 53(9), 1689-1699. https://doi.org/10.1017/CBO9781107415324.004

[5] Harbani, Arif, and Ari Fajrianto. "Sistem Informasi Nilai Akademik Mahasiswa Menggunakan Teknik Json dan Nfc." Teknois, vol. 9, no. 2, 30 Nov. 2019, pp. 79-90, doi:10.36350/jbs.v9i2.68.

[6] Hermiyanty, Wandira Ayu Bertin, D. S., 2017. No Title No Title. Journal of Chemical Information and Modeling, 8(9), 1-58. https://doi.org/10.1017/CBO9781107415324.004

[7] Darmawan, E., \& Santoso, S., 2017. Perancangan dan Pembuatan Sistem Pengumuman Akademis Berbasis Tag Menggunakan REST Web Service. Jurnal ULTIMA InfoSys, 8(1), 48-53. https://doi.org/10.31937/si.v8i1.556

[8] Mohd Omar, N. A., Azmi, N. J., \& Ahamad Sani, N., 2020. Is Whatsapp the Future of Workplace Communication?: Investigating the Use of Whatsapp in Decision- Making Episodes. Journal of Nusantara Studies (JONUS), 5(1), 414-442. https://doi.org/10.24200/jonus.vol5iss1pp414-442

[9] Darmawan, E., \& Santoso, S., 2017. Perancangan dan Pembuatan Sistem Pengumuman Akademis Berbasis Tag Menggunakan REST Web Service. Jurnal ULTIMA InfoSys, 8(1), 48-53. https://doi.org/10.31937/si.v8i1.556 